\title{
THE IRONY OF HOSANNA-TABOR EVANGELICAL LUTHERAN CHURCH \& SCHOOL V. EEOC
}

\author{
Caroline Mala Corbin*
}

\section{INTRODUCTION}

The question presented in Hosanna-Tabor Evangelical Lutheran Church \& School v. EEOC is whether or not a schoolteacher should be considered a minister. ${ }^{1}$ Although the school teacher in this case, Cheryl Perich, began her employment as a lay teacher, she soon became a called teacher with the title "commissioned minister." 2 She taught a religion class four times a week and led her class in daily prayers. ${ }^{3}$ During the bulk of her workday, however, Perich taught math, reading, English, social studies, science, gym, art, and music to third and fourth graders. ${ }^{4}$

Perich claims the school retaliated against her in violation of the Americans with Disability Act (ADA). During the summer of 2004, Perich became seriously ill. ${ }^{5}$ She took disability leave when school started in the fall and was eventually diagnosed with narcolepsy. ${ }^{6}$ In January 2005, Perich informed the school principal that her doctor had cleared her to return to work. ${ }^{7}$ In response, the principal voiced concerns about the safety of students under Perich's care. ${ }^{8}$ The school board then expressed its opinion that Perich would not be physically capable of returning to work and requested that she resign in exchange for assistance with her health insurance. ${ }^{9}$ Perich declined the offer. ${ }^{10}$ Her doctor released her to return to work on February 22, 2005, effectively ending her disability coverage. When Perich reported for work on February 22, the school did not have a job for her. ${ }^{11}$ Because the school handbook states that failure to return to

\footnotetext{
* Associate Professor of Law, University of Miami School of Law.

1 131 S. Ct. 1783 (2011) (link).

2 EEOC v. Hosanna-Tabor Evangelical Lutheran Church \& Sch., 597 F.3d 769, 772 (6th Cir. 2010) (link).

${ }^{3} I d$.

${ }^{4}$ Id. Teaching these subjects occupied all but forty-five minutes of each seven hour day. Id. In teaching these classes, she used the same textbooks as used in public schools. Id. at 773.

5 Id. at 773.

${ }^{6}$ Id. ("Throughout her leave, Perich regularly provided [the principal] with updates about her condition and progress.").

7 Id.

8 Id.

9 Id. at 774 .

${ }^{10} \mathrm{Id}$.

11 Id.
} 
work the day after an approved medical leave expires may be considered a voluntary termination, Perich refused to leave school grounds without a letter acknowledging she had appeared for work. ${ }^{12}$ After Perich told the principal that she would sue for disability discrimination, she was fired. ${ }^{13}$ Correspondence from the school indicated that she lost her job because of her insubordination and her threats to take legal action. ${ }^{14}$ Under the ADA, it is illegal for an employer to retaliate against an employee for bringing or threatening to bring a disability discrimination suit. ${ }^{15}$

The success of Perich's ADA claim turns on whether the Supreme Court finds that she is a minister. If she is not a minister, she will probably win. After all, the school stated in writing that a main reason for Perich's termination was her threatened lawsuit. If, on the other hand, she is a minister, she will lose. She will lose because, under the ministerial exception doctrine, ministers may not sue their employers for discrimination. ${ }^{16}$

The ministerial exception grants religious organizations immunity from employment discrimination suits by ministers even if the discrimination is not religiously required. ${ }^{17}$ Thus, even if the tenets of the Hosanna-Tabor Evangelical Lutheran Church forbid discrimination on the basis of disability - and in fact their Governing Manual for Lutheran Schools states that the school will not discriminate on these grounds ${ }^{18}$ - ministers cannot sue the school for disability discrimination. The lower courts, who created and uniformly apply the ministerial exception, claim that the First Amendment's religion clauses require it. ${ }^{19}$ According to the lower courts, interfering with clergy employment decisions would undermine the church autonomy guaranteed by the Free Exercise Clause. Furthermore, they fear that these suits would lead to entanglement with religious doctrine and therefore violate the Establishment Clause. ${ }^{20}$

12 Id.

13 Id. at 774-75.

14 Id. According to a March 19, 2005 letter from the school board, the school board was going to request that her call be rescinded because of her "insubordinate and disruptive behavior" on the day she reported back to school, and because she had "damaged, beyond repair" her working relationship with the school by "threatening to take legal action." Id. at 774 .

1542 U.S.C. § 12203(a) (2006) (link).

16 See Hosanna-Tabor, 597 F.3d at 776.

17 See, e.g., McClure v. Salvation Army, 460 F.2d 553, 558-61 (5th Cir. 1972) (applying the ministerial exception even though the Salvation Army never claimed the alleged discrimination was religiously mandated) (link).

18 Id. at 782 ("[T]he LCMS personnel manual, which includes EEOC policy, and the Governing Manual for Lutheran Schools clearly contemplate that teachers are protected by employment discrimination and contract laws.").

19 See, e.g., Hollins v. Methodist Healthcare, Inc., 474 F.3d 223, 225 (6th Cir. 2007) (link); McClure, 460 F.2d at 560.

20 See Caroline Mala Corbin, Above the Law? The Constitutionality of the Ministerial Exemption from Antidiscrimination Law, 75 FORDHAM L. REV. 1965, 1973-81 (2007) (explaining the origins, 


\section{NORTHWESTERN UNIVERSITY LAW REVIEW COLLOQUY}

They are mistaken. Neither the Free Exercise Clause nor the Establishment Clause necessitates the ministerial exception. As a neutral law of general applicability, the ADA does not violate the Free Exercise Clause. Furthermore, trying to discern whether or not Perich is a minister creates more Establishment Clause problems than simply resolving her retaliation claim.

\section{FREE EXERCISE CLAUSE JUSTIFICATION}

\section{A. Employment Division v. Smith}

The ministerial exception was created before Employment Division v. Smith announced a major shift in free exercise jurisprudence. Employment Division v. Smith held that as long as a law is neutral and generally applicable, it does not violate the Free Exercise Clause even if it imposes a substantial burden on religion. ${ }^{21}$ Smith itself upheld a law that made a religious sacrament illegal. ${ }^{22}$ Because the ADA is both neutral and generally applicable, Smith should defeat any free exercise justification.

Nonetheless, courts and commentators have insisted that Smith applies only to individual free exercise claims and not to institutional ones. ${ }^{23}$ They claim Smith makes this distinction when it notes that " $[\mathrm{t}]$ he government may not ... lend its power to one or the other side in controversies over religious authority or dogma." 24 They argue for "church autonomy" in matters of internal governance and, as support, point to a line of church property cases (several mentioned by Smith) where the Supreme Court has deferred to the church hierarchy. ${ }^{25}$ Consequently, they argue, courts should

development, and justifications for ministerial exception) (link). Hosanna-Tabor represents the first time that the Supreme Court will address the ministerial exception.

21494 U.S. 872, 879, 882-83 (1990) (link).

22 Id. at 874 (recognizing that plaintiffs' use of peyote was a sacrament in their Native American Church); id. at 890 (denying plaintiffs an exemption from the Federal Controlled Substance Act that made such sacramental use illegal). It is beyond the scope of this essay to discuss whether Smith was correctly decided. Perhaps exemptions that do not impose burdens on others ought to be required under the Free Exercise Clause, although such a claim would have to explain why religious but not equally strong secular moral commitments are protected. In any case, exemptions for religious employers from antidiscrimination law clearly impose a significant burden on those seeking the protection of those laws.

23 See, e.g., EEOC v. Catholic Univ. of Am., 83 F.3d 455, 461-63 (D.C. Cir. 1996) (link); Douglas Laycock, The Supreme Court and Religious Liberty, 40 CATH. LAW. 25, 36 (2000).

24 Emp't Div. v. Smith, 494 U.S. at 877 (internal citations omitted). They read "religious authority" as a reference to church hierarchy and those who lead the church rather than as a reference to religious texts. See, e.g., Michael W. McConnell, The Problem of Singling Out Religion, 50 DePaul L. Rev. 1, 4, 19-20 (2000) (stating that Smith reaffirmed a church's autonomy regarding its internal governance). Nevertheless, the latter interpretation reads better in the context of the sentence, whose language about taking sides in religious disputes draws from Establishment Clause constraints. Furthermore, had the Supreme Court meant to exclude churches from its new rule, one would have expected it to do so more explicitly rather than rely on one possible interpretation of "authority" in the phrase "religious authority and dogma."

25 Serbian E. Orthodox Diocese v. Milivojevich, 426 U.S. 696 (1976) (link); Presbyterian Church v. 
likewise defer to church employers when it comes to employment discrimination suits involving their ministers. ${ }^{26}$ A minister, after all, "serves as the church's public representative, its ambassador, and its voice to the faithful." ${ }^{27}$ Furthermore, the deference should be absolute, so that in all discrimination cases, the minister loses.

To be sure, in deferring to the highest church authority, the Supreme Court did recognize a degree of church autonomy. However, animating the Court's recognition of church autonomy was the Establishment Clause concern that the state would entangle itself in theological or doctrinal disputes. $^{28}$ The Establishment Clause bars the courts from resolving theological or doctrinal disputes, or endorsing one version of religious truth over another. ${ }^{29}$ The state is considered incompetent in these religious matters. For example, in Presbyterian Church v. Mary Elizabeth Blue Hull Memorial Presbyterian Church (the first church property case cited in Smith), the Supreme Court invalidated a Georgia law that required the courts to resolve a property dispute between a general church and breakaway local churches by deciding whether the general church had departed from the religious tenets it held at the time the local churches first affiliated with it. ${ }^{30}$ Entanglement concerns also explain the holdings of the two other cases cited by Smith. ${ }^{31}$

In addition, reliance on this line of cases is misplaced because it ignores Jones $v$. Wolf, ${ }^{32}$ the last church property dispute decided by the

Mary Elizabeth Blue Hull Mem'l Presbyterian Church, 393 U.S. 440 (1969) (link); Kedroff v. Saint Nicholas Cathedral of Russian Orthodox Church, 344 U.S. 94 (1952) (link); Watson v. Jones, 80 U.S. (13 Wall.) 679 (1871) (link).

26 See generally Thomas C. Berg, Kimberlee Wood Colby, Carl H. Esbeck, \& Richard W. Garnett, Religious Freedom, Church-State Separation, \& the Ministerial Exception, 106 Nw. U. L. REV. COLLOQUY (forthcoming 2011).

27 Petruska v. Gannon Univ., 462 F.3d 294, 306 (3d Cir. 2006) (link); see also McClure v. Salvation Army, 460 F.2d 553, 559 (5th Cir. 1972) ("The minister is the chief instrument by which the church seeks to fulfill its purpose.").

28 See, e.g., Jones v. Wolf, 443 U.S. 595, 602 (1979) (“[T]he First Amendment severely circumscribes the role that civil courts may play in resolving church property disputes. Most importantly, the First Amendment prohibits civil courts from resolving church property disputes on the basis of religious doctrine and practice." (emphasis added) (internal citations and quotation marks omitted)) (link).

29 Thus, as examples, the state cannot declare that Catholics practice the correct version of Christianity or that the Catholic Mass is properly performed in Latin rather than English.

30393 U.S. at 441, 449-50. In fact, the Supreme Court in Presbyterian Church did not actually defer to the church hierarchy. See id. at 449-51.

31 In Kedroff v. Saint Nicholas Cathedral of the Russian Orthodox Church, the Supreme Court rejected the New York legislature's finding that one faction would better carry out the church's mission and opted for deference to the highest church body. 344 U.S. 94, 106 n.10, 107-09, 117-18 (1952). In Serbian Eastern Orthodox Diocese v. Milivojevich, the Supreme Court declined to rule on whether the church properly applied its own policies. 426 U.S. 696, 709 (1976). Notably, the case does not address the issue of the Court's competency to rule on whether the church failed to abide by state laws.

32443 U.S. 595 (1979). 
Supreme Court. As the most recent case involving churches rather than individuals, its precedential value cannot be ignored. ${ }^{33}$ And in Jones $v$. Wolf, the Court explicitly rejects blanket deference to religious institutions.

\section{B. Jones v. Wolf}

Like previous church property disputes, Jones $v$. Wolf involved a schism within a church. A majority of the Vineville church in Macon, Georgia, voted to separate from the Presbyterian Church in the United States. $^{34}$ Both the majority congregation and the minority that wished to remain affiliated with the Presbyterian Church in the United States claimed the church property as its own. ${ }^{35}$

The Supreme Court rejected a rule requiring it to defer to the church hierarchy of the Presbyterian Church in the United States:" "We cannot agree, however, that the First Amendment requires . . . a rule of compulsory deference to religious authority in resolving church property disputes, even where no issue of doctrinal controversy is involved." ${ }^{37}$

Instead, the Supreme Court endorsed a neutral principles of law approach: "We therefore hold that a State is constitutionally entitled to adopt neutral principles of law as a means of adjudicating a church property dispute." ${ }^{38}$ In other words, the Court endorsed resolving the church's property dispute in the same way that it would resolve the property dispute of a secular organization. Thus, the Court approved of "examin[ing] the deeds to the properties, the state statutes dealing with implied trusts, and the Book of Church Order to determine whether there was any basis for a trust in favor of the general church." 39

The Supreme Court realized that Establishment Clause issues may arise under a neutral principles of law approach. ${ }^{40}$ Nevertheless, the neutral

${ }^{33}$ In addition to misreading the church property cases, the claim that Employment Division v. Smith applies only to individual and not institutional free exercise claims also overlooks the general shift in religion clause jurisprudence - a shift that Smith embodies - towards more equal treatment of religion and nonreligion. See Corbin, supra note 20, at 1990-96. Also, providing religious individuals with no protection from neutral laws of general applicability while protecting absolutely religious institutions privileges the derivative right over the original, individual right to free exercise. See id. at 1987-89.

34 Jones, 443 U.S. at 598.

35 Id.

${ }^{36} I d$. at 604-05 ("The dissent ... would insist as a matter of constitutional law that whenever a dispute arises over the ownership of church property, civil courts must defer to the authoritative resolution of the dispute within the church itself." (internal quotations omitted)).

37 Id. at 605; accord id. at 602 ("[T] he First Amendment does not dictate that a State must follow a particular method of resolving church property disputes.").

38 Id. at 604.

39 Id. at 600 (internal citations omitted). In other words, the Court expressly contemplated that the courts would look at religious documents like a church constitution for language of trust. Id. at 604 .

${ }^{40} I d$. at 604 ("This is not to say that the application of the neutral-principles approach is wholly free of difficulty. ... If in such a case the interpretation of the instruments of ownership would require the civil court to resolve a religious controversy, then the court must defer to the resolution of the doctrinal 
principles approach is constitutional "so long as it involves no consideration of doctrinal matters, whether the ritual and liturgy of worship or the tenets of faith." ${ }^{11}$ Thus, the possibility that Establishment Clause issues may surface under a neutral principles of law approach does not preclude such an approach. Perhaps that bears repeating: Just because an Establishment Clause issue may arise in the adjudication of a particular type of claim does not mean that the Court must forever abandon trying to resolve such a claim using neutral principles of law. ${ }^{42}$

Furthermore, the Jones Court recognized that a deference approach does not eliminate all Establishment Clause problems. When church structure is ambiguous, determining which unit of the church governance has ultimate control might well result in entanglement with church doctrine. ${ }^{43}$ In that case, it is actually the neutral principles of law approach that can best avoid entanglement because it "obviates entirely the need for an analysis or examination of ecclesiastical polity or doctrine ...." ${ }^{44}$

In short, controlling precedent does not require that the courts simply defer to the Hosanna-Tabor Evangelical Lutheran Church and School in this internal governance dispute. Instead, courts may resolve this retaliation claim in much the same way they resolve any other retaliation claim. Only if adjudication of this claim entangles a court in theological or doctrinal questions should the court opt for deference to church authorities. This conclusion is especially true because, as Jones $v$. Wolf acknowledges, a deference approach might actually cause more Establishment Clause ills than a neutral principles of law approach.

\section{ESTABLISHMENT Clause JUSTIFICATION}

\section{A. Neutral Principles of Law Approach: Resolving the Retaliation Claim}

Supporters of the ministerial exception retort that resolving discrimination claims violates the Establishment Clause because their adjudication requires courts to evaluate a minister's spiritual qualifications or determine whether a minister sufficiently embodies the church and its teachings. ${ }^{45}$ Even assuming some employment discrimination cases might

\footnotetext{
issue by the authoritative ecclesiastical body.").

41 Id. at 602 (quoting Maryland \& Va. Churches v. Sharpsburg Church, 396 U.S. 367 (1970) (Brennan, J., concurring) (link)).

42 See id. at 604 ("On balance, however, the promise of nonentanglement and neutrality inherent in the neutral-principles approach more than compensates for what will be occasional problems in application.").

43 See id. at 605.

44 Id.

45 Thomas C. Berg, The Voluntary Principle and Church Autonomy, Then and Now, 2004 BYU L. REV. 1593, 1613 (link); see also Rweyemamu v. Cote, 520 F.3d 198, 209 (2d Cir. 2008) (stating that the court could not "imagine an area of inquiry less suited to a temporal court for decision [than] evaluation of the 'gifts and graces' of a minister" (quoting Minker v. Baltimore Annual Conference of United
} 
present these Establishment Clause problems, not all do. ${ }^{46}$ Perich's claim in Hosanna-Tabor does not. Consequently, the Establishment Clause cannot justify the blanket immunity that the ministerial exception provides.

It is incorrect to assume that adjudicating ministers' anti-discrimination claims will require courts to decide questions beyond their institutional competence. A court may easily resolve Perich's retaliation claim without becoming entangled with doctrinal or theological questions. In order to win her retaliation suit, Perich must prove that (1) she engaged in activity protected by the ADA; (2) she suffered a materially adverse action; and (3) there was a causal link between the protected activity and the adverse action. ${ }^{47}$

As the Sixth Circuit concluded, "contrary to Hosanna-Tabor's assertions, Perich's claims would not require the court to analyze any church doctrine."48 Perich's protected activity was the assertion of her legal rights under the ADA, and the adverse action was her termination. As in most retaliation cases, the pivotal question is whether the assertion of her legal rights caused her termination. ${ }^{49}$ It is uncontested that the school sent

\footnotetext{
Methodist Church, 894 F.2d 1354 (D.C. Cir. 1990))) (link); Brief for the Petitioner at 14, HosannaTabor Evangelical Lutheran Church \& Sch. v. EEOC, No. 10-553 (June 13, 2011) ("The Establishment Clause also prevents courts from deciding the religious questions that are inevitably involved in employment disputes over ministers.") (link).

${ }^{46}$ For example, Title VII sex harassment cases and Fair Labor Standard Act wage and hours cases do not involve reinstatement or evaluation of the plaintiff-minister's "gifts and graces." Indeed, these cases are unrelated to the church's selection of its representatives and control of its voice, and therefore, they should not fall within the purview of the ministerial exception. For just this reason, several courts have held that the ministerial exemption should not apply to sexual harassment cases. See, e.g., Bollard v. Cal. Province of the Soc'y of Jesus, 196 F.3d 940, 944 (9th Cir. 1999) (link). The same should hold true for wage and hour cases under the Fair Labor Standards Act. See, for example, Shaliehsabou v. Hebrew Home of Greater Washington, Inc.:
}

[T]he requirement that the Hebrew Home pay employees, like Shaliehsabou, overtime does not require the government — or the court — to question the Hebrew Home's religious beliefs, inquire into the religious nature of the activities that Shaliehsabou performs, or to become involved in any way in the governance or functioning of the institution.

369 F.3d 797, 805 (4th Cir. 2004) (Luttig, J., dissenting from denial of rehearing en banc) (link).

47 See, e.g., Barrett v. Whirlpool Corp., 556 F.3d 502, 516 (6th Cir. 2009) (link); Bryson v. Regis Corp., 498 F.3d 561, 577 (6th Cir. 2007) (link).

48 EEOC v. Hosanna-Tabor Evangelical Lutheran Church \& Sch., 597 F.3d 769, 781 (6th Cir. 2010).

49 It is worth noting that case law is unclear about whether Perich needs to prove that retaliation was the but-for cause, or merely one cause, of her termination. The Civil Rights Act of 1991 clarified that discrimination need only be "a motivating factor" for liability under Title VII. Lower courts differ about whether this standard also applies to suits under the ADA and other anti-discrimination statutes. Compare Serwatka v. Rockwell Automation, Inc., 591 F.3d 957, 962 (7th Cir. 2010) (applying the "butfor" standard to an ADA claim) (link), with Martin v. Cal. Dept. of Veterans Affairs, 560 F.3d 1042, 1048 (9th Cir. 2009) (applying the "motivating factor" standard to an ADA claim) (link). 
her a letter stating that the school board intended to fire her because her threatened legal action ruined her working relationship with the school. ${ }^{50}$ Thus, unlike most cases, Perich has direct evidence of retaliation. ${ }^{51}$

\section{Main Religious Claim Is a Free Exercise Claim}

Hosanna-Tabor nevertheless argues that there is a religious question because Perich was fired for being insubordinate and spiritually unfit. ${ }^{52}$ First, she had been unruly and disruptive when asserting her legal rights, thereby ruining her relationship with the school. ${ }^{53}$ Second, instead of trusting the church's mandatory dispute resolution process, Perich sued in court. $^{54}$ Of course, in a secular context, firing someone for asserting her legal rights is the very definition of retaliation and is illegal no matter how disruptive, insubordinate, or infuriating the employer may find it. Moreover, any contract where the employee has signed away all rights to bring a discrimination claim against her employer is void as against public policy. ${ }^{55}$ That is, a contractual provision stipulating that all discrimination claims will be resolved internally rather than before a neutral third party is unenforceable. ${ }^{56}$ Does the religious context, however, change the retaliation question into a religious question, the resolution of which violates the Establishment Clause? Hosanna-Tabor's argument boils down to this: a religious organization should be able to proclaim ministers spiritually unfit

50 Hosanna-Tabor, 597 F.3d at 774.

51 The principal sent Perich a letter stating that due to her disruptive behavior on the day she reported back to work, the board would request her termination. Id. The letter also stated that she had "damaged, beyond repair" her working relationship with the school by "threatening to take legal action." Id.

52 According to the school, Perich was fired "because her insubordination and threats of litigation violated Church teaching." Petition for a Writ of Certiorari at 6, Hosanna-Tabor, No. 10-533 (Oct. 22, 2011) (link).

53 Hosanna-Tabor, 597 F.3d at 774.

54 See id. at 782.

55 Employees may not by contract prospectively waive their civil rights:

[W] think it clear that there can be no prospective waiver of an employee's rights under Title VII.... Title VII's strictures are absolute and represent a congressional command that each employee be free from discriminatory practices.... [W]aiver of these rights would defeat the paramount congressional purpose behind Title VII.

Alexander v. Gardner-Denver Co., 415 U.S. 36, 50-51 (1974) (link).

56 While employees may agree to bring civil rights claims before a neutral third party arbitrator rather than in court, the agreement is valid only if "the prospective litigant effectively may vindicate [his or her] statutory cause of action in the arbitral forum." Gilmer v. Interstate/Johnson Lane Corp., 500 U.S. 20, 28, 30 (1991) (allowing arbitration clauses for civil rights claims on the assumption that the arbitrator will be a "conscientious and impartial" arbiter and noting that the applicable arbitration rules "provide protection against biased panels") (link). It is doubtful that Hosanna-Tabor's "internal dispute resolution" process would even qualify as arbitration, much less meet this standard. 
anytime they assert their legal rights or insist that the church follow the law, and for the secular courts to disagree with this assessment violates the Establishment Clause.

Again, a court could avoid all Establishment Clause issues and still resolve this retaliation claim. To be sure, the Court would violate the Establishment Clause if it declared what the church's true beliefs were with regard to insubordination among its ministers. But the Court could assume that under Evangelical Lutheran Church tenets dissension can compromise a minister's spirituality and even that it was spiritual unfitness and not pique or financial considerations ${ }^{57}$ that motivated Perich's dismissal in this case, ${ }^{58}$ and still hold that the church violated the law. How? HosannaTabor's claim that Perich was spiritually unfit because she threatened legal action does not in fact deny that her legal conduct caused her termination. Instead, the argument is that the retaliation is religiously required. Nonetheless, it is still an admission of retaliation.

Thus, under one understanding of the case, to the extent there is a religious question, it is really a free exercise question. In other words, assuming that Perich is a minister and that Perich's assertion of her legal rights compromises her spiritual fitness, is Hosanna-Tabor nonetheless liable under the ADA? The question before the Court does not require interpreting religious doctrine or tenets, or even ascertaining the school's real motives. Instead, the Court must decide whether a neutral law of general applicability (retaliation is illegal) supersedes a religious obligation (retaliation is religiously required). Under Employment Division v. Smith, as long as the law is neutral and generally applicable, it does not matter if it substantially burdens a religious practice. ${ }^{59}$

57 When Perich went on leave, the school hired a replacement for the rest of the year instead of hiring someone for a more limited time frame. As a result, the school could not lay off the replacement if Perich were to return. Thus, it was in its financial interest to terminate Perich.

58 This is a big assumption, and a court might well decide that the claim is merely pretext for discrimination rather than sincere. This is the same determination courts regularly make in discrimination claims. See Corbin, supra note 20, at 2016-22 (explaining why pretext analysis does not require courts to become entangled in theological or doctrinal issues). For example, Perich might offer evidence that another teacher threatened to sue for breach of contract yet did not lose his job.

Indeed, in Ohio Civil Rights Commission v. Dayton Christian Schools, Inc., a case that parallels this one, the Supreme Court gave its blessing to a pretext analysis. 477 U.S. 619 (1986) (link). In that case, a born-again Christian school told a pregnant teacher she could not return to school the following year because of its belief that mothers should stay home with their preschool children. Id. at 623 . When she threatened litigation, the school fired her for violating the mandatory internal dispute resolution provision in her contract, arguing that Christians should not sue other Christians. Id. While the ultimate holding focused on abstention issues, the Supreme Court noted that "the Commission violates no constitutional rights by merely investigating the circumstances of [the schoolteacher's] discharge in this case, if only to ascertain whether the ascribed religious-based reason was in fact the reason for the discharge." Id. at 628.

59 In effect, if it does not violate the Free Exercise Clause for the state to ban a sacrament, as it did in Smith, then it does not violate the Free Exercise Clause for the state to regulate those who might administer a sacrament. Although here, of course, Perich is not administering any sacraments, and the 
Of course, even before Employment Division v. Smith, the fact that a law burdened a religious tenet did not guarantee an exemption from that law. Even if a church's religious tenets required that insubordinate ministers be flogged, courts are not likely to exempt it from criminal assault law. ${ }^{60}$ If the Court accepted the school's all-litigious-ministers-arespiritually-deficient argument, the church could dismiss as insubordinate and spiritually unfit a minister who was raped by a coworker and brings a sexual assault charge. A church could also terminate without interference a minister who threatens to sue after the church breached its contract and failed to pay the agreed-upon salary. Likewise, a church, religious school, or religious hospital could fire as insubordinate and spiritually unfit a minister who reports any wrongdoing, whether it be discrimination, embezzlement, or the sexual abuse of children. In short, letting a religious organization claim that a minister who insists on compliance with the law is spiritually unfit creates a potentially limitless loophole and allows it to be a "law unto itself." 61

\section{Reinstatement Issue}

Does this mean that a church or religious school must keep a minister it views as unqualified? Not necessarily. If a case presents a free exercise question and there is no doubt that reinstatement would violate a religious tenet, a compromise position might be to limit the remedy to damages. ${ }^{62}$ However, this alternative remedy should be used sparingly. After all, if a minister was fired because of her disability (or age or race or sex) and the church employer has no religious tenets requiring dismissal of people due to disability (or age or race or sex), then there should be no problem with letting her resume her post. Indeed, if discrimination distorted the decisionmaking process, then reinstatement would merely correct a church

\footnotetext{
issue before the Court is whether she should even be considered a minister.

${ }^{60}$ Indeed, courts have held that anti-discrimination laws trump religious views. For example, courts have held that religious schools must comply with Title VII and the Equal Pay Act even though their religious tenets regard married men as heads of households and require providing them with better health insurance or salaries than married women. See, e.g., EEOC v. Fremont Christian Sch., 781 F.2d 1362, 1364 (9th Cir. 1986) (holding that the state could require a school to violate its religious tenets and provide health insurance to married women as well as to singles and married men) (link); EEOC v. Tree of Life Christian Schs., 751 F. Supp. 700, 716-17 (S.D. Ohio 1990) (holding that the state could require a school to violate its religious tenet and pay married women the same compensation as married men) (link); see also Tony \& Susan Alamo Found. v. Sec'y of Labor, 471 U.S. 290, 303-06 (1985) (holding that the state could force a religious organization to violate its religious beliefs and pay minimum wage as required by the Fair Labor Standards Act) (link).

${ }^{61}$ Cf. Emp't Division v. Smith, 494 U.S. 872, 879 (1990) (arguing that the effect of granting exemptions to neutral laws of general applicability "would be to make the professed doctrines of religious belief superior to the law of the land" and would allow the religious observer "to become a law unto himself').

62 This is in contrast to cases where there is reason to believe that the religious justification is a pretext for discrimination.
} 


\section{NORTHWESTERN UNIVERSITY LAW REVIEW COLLOQUY}

mistake. ${ }^{63}$

In addition to damages as an alternate remedy to reinstatement, there may be constitutional protection for the church-clergy relationship, often described as the "lifeblood" of the church. Boy Scouts of America v. Dale, which allowed the Boy Scouts to violate anti-discrimination laws on the grounds that the presence of a gay scoutmaster would undermine the Boy Scouts' anti-homosexual message, ${ }^{64}$ strengthened the First Amendment freedom of association guaranteed by the Free Speech Clause. Like other associations, churches have a free speech interest in selecting those who represent and speak for them and, arguably, an associational right not to be forced to hire or rehire a minister whose presence would undermine their religious messages. ${ }^{65}$ However, for Hosanna-Tabor's decision to fire Perich to be protected to the same degree as the Boy Scouts' decision in Dale, Hosanna-Tabor would have to establish that keeping Perich as a third and fourth grade teacher would distort a religious message. ${ }^{66}$ Even then, the decision may still be illegal if the Court deems the anti-retaliation law to be sufficiently tailored to advance a sufficiently important government interest. ${ }^{67}$

\section{B. Church Deference Approach: Deciding Whether Perich Is a Minister}

The irony of this case is that while resolving this retaliation suit will not embroil the Court in theological or doctrinal disputes, applying the ministerial exception will. Thus, this case presents an example of how a church autonomy or deference approach presents more Establishment Clause problems than a neutral principles of law approach.

To trigger the ministerial exception, the plaintiff in a discrimination suit must be a "ministerial" employee. In determining who counts as a ministerial employee, courts do not simply accept a religious employer's characterization of a position, as it could insist that all of its employees

${ }^{63}$ In other words, then, reinstatement might actually benefit the church by restoring to it someone it would have employed but for unsanctioned discrimination. See Corbin, supra note 20, at 2023.

64530 U.S. 640, 653-56 (2000) (link).

65 Religions that limit their clergy positions to men may continue the practice on the grounds that admitting women would undermine their religious messages about the nature of ministry or the proper roles of men and women.

66 To the extent that establishment issues may come up, they differ from those that arise in applying the ministerial exception. To start, it is much more problematic to encounter an Establishment Clause issue in applying in the ministerial exception when the very reason for its existence is to avoid Establishment Clause issues. In addition, the question asked in applying the ministerial exceptiondoes this person perform religiously important duties-necessarily involves delving into religious doctrine and beliefs. The questions asked in resolving a freedom of association claim-does the religious employer have a religious message and does the presence of a particular employee distort that message - do not involve delving into religious doctrine and beliefs, especially if the court is deferential with regard to the first question.

67 Boy Scouts, 530 U.S. at 657-58 (balancing expressive associational interests against antidiscrimination goals of public accommodation law). 
were ministers. ${ }^{68}$ Instead, courts take a functional approach. ${ }^{69}$ In the Sixth Circuit, Perich is a minister if her "primary duties consist of teaching, spreading the faith, church governance, supervision of a religious order, or supervision or participation in religious ritual and worship." 70

This query "necessarily requires a court to determine whether a position is important to the spiritual and pastoral mission of the church." But in order to decide whether Perich's primary teaching duties are important to the spiritual and pastoral mission of the church, the Court might have to delve into the religious beliefs of the Evangelical Lutheran Church.

Teaching religion classes and leading prayers are clearly religious activities and would readily qualify as religious duties. Yet these tasks only account for approximately forty-five minutes out of Perich's seven-hour work day, which is roughly eleven percent of her time. ${ }^{72}$ If those activities were her only religious duties, then she would not count as a minister under the primary duties test. However, what about the fact that she also serves as a Christian role model for her students? That is an activity she performs all day, every day. If that were a religiously important function, then she may well qualify as a minister under the primary duties test. "According to Perich, using secular textbooks to teach secular subjects is a secular activity; but according to the Church, the same activity is religious because all teachers are required to serve as fine Christian role models." 73 But whether serving as a role model is religiously important-not whether it is important in general, but whether it is important to the Hosanna-Tabor Evangelical Lutheran Church's spiritual and pastoral mission-is not a question the Court should answer. ${ }^{74}$ Courts should not mediate a dispute about what is or is not important to a church's pastoral mission or resolve a theological dispute about the religious role of schoolteachers.

Hosanna-Tabor concedes that the primary duties test invites

68 See, e.g., Dole v. Shenandoah Baptist Church, 899 F.2d 1389, 1396 (4th Cir. 1990) (a school claimed that all its teachers "consider teaching to be their personal ministry") (link); EEOC v. Sw. Baptist Theological Seminary, 651 F.2d 277, 283 (5th Cir. 1981) (a seminary claimed that all its employees, including support staff, served a ministerial function) (link).

69 Tomic v. Catholic Diocese of Peoria, 442 F.3d 1036, 1039 (7th Cir. 2006) ("[I]f to avoid having to pay the minimum wage to its janitor a church designated all its employees 'ministers,' the court would treat the designation as a subterfuge.") (link).

70 EEOC v. Hosanna-Tabor Evangelical Lutheran Church \& Sch., 597 F.3d 769, 778 (6th Cir. 2010) (quoting Shaliehsabou v. Hebrew Home of Greater Wash., Inc., 369 F.3d 797, 803 (4th Cir. 2004)).

71 Rayburn v. Gen. Conference of Seventh Day Adventists, 772 F.2d 1164, 1169 (4th Cir. 1985) (link).

72 Hosanna-Tabor, 597 F.3d at 772.

73 Petition for a Writ of Certiorari, supra note 52, at 16.

74 Cf. Corbin, supra note 20, at 2028 (discussing the distinction between deciding whether something is religiously true and evaluating the credibility of religious reasons). 
Establishment Clause problems. ${ }^{75}$ To mitigate these problems, it suggests that the Court should replace the primary duties test with a religious duties test, where the question is whether the employee had performed any important religious duties. ${ }^{76}$ Although this solution expands the ministerial exception, it does not solve the underlying Establishment Clause issues.

To start, unless courts are willing to categorize anyone who performs even one religious task as a minister, courts still have to draw the quantitative line somewhere. Otherwise a school can make everyone a minister by ensuring that each and every school employee, from the janitor to the bookkeeper to the P.E. teacher, leads a prayer at least once or twice during the school year. As a result, no one who works for a religious school, hospital, nursing home, social service organization, or church would have any employment protections.

In any event, even if the Court alters the threshold amount of religious duties that the ministerial exception requires, courts may still have to determine whether a particular duty was religiously "important." What if Perich only taught secular subjects? Or what if, instead of a schoolteacher for the Evangelical Lutheran Church, she served as its music director? In order to decide whether a music director is a minister, the Court would have to rule on the religious significance of music in the Evangelical Lutheran Church. ${ }^{77}$ Again, this test wrongly places courts in the position of deciding whether music is integral to a denomination's worship services or important enough that teaching it makes someone a minister. Resolving theological disputes about the significance of music to worship is exactly the kind of doctrinal issue the courts are incompetent to make, yet it is exactly the kind of decision that application of the ministerial exception may require. ${ }^{78}$

\section{CONCLUSION}

People who wish to serve their God should not have to choose between their calling and their civil rights. Yet, the ministerial exception essentially strips ministers of protection against discrimination based on race, ${ }^{79}$ sex, ${ }^{80}$

75 Petition for a Writ of Certiorari, supra note 51, at 12-14 (agreeing that forcing courts to decide which duties are secular and which are religious leads to religious entanglement).

76 Brief for the Petitioner, supra note 45, at 22. Hosanna-Tabor also suggests that the Court should defer and let the religious institution decide if a duty is religiously important. Id. at 48-49. But without some kind of functional analysis, a religious organization can essentially claim that every employee does some duty that is religiously important. See supra notes 68-69.

77 See EEOC v. Roman Catholic Diocese of Raleigh, N.C., 213 F.3d 795, 802 (4th Cir. 2000) (link).

78 One appeals court noted that "[t]he very invocation of the ministerial exception requires us to engage in entanglement with a vengeance." Elvig v. Calvin Presbyterian Church, 397 F.3d 790, 797 (9th Cir. 2005) (link).

79 See, e.g., Alicea-Hernandez v. Catholic Bishop of Chicago, 320 F.3d 698, 704 (7th Cir. 2003) (holding that a Hispanic communications manager could not bring a Title VII national origin claim) (link); Ross v. Metro. Church of God, 471 F. Supp. 2d 1306, 1308-12 (N.D. Ga. 2007) (holding that a Director of Worship Arts (a music director) is barred from bringing a $§ 1981$ claim) (link).

${ }^{80}$ See, e.g., Petruska v. Gannon Univ., 462 F.3d 294, 299 (3d Cir. 2006) (holding that a college 
age, ${ }^{81}$ and, as here, disability, and leaves them outside the shelter of the Family Medical Leave Act, ${ }^{82}$ the Fair Labor Standards Act, ${ }^{83}$ the Equal Pay Act ${ }^{84}$ and a host of other protective employment laws. ${ }^{85}$

This absolute immunity from lawsuits cannot be justified by either the Free Exercise Clause or the Establishment Clause. The ADA is a neutral law of general applicability and therefore does not violate the Free Exercise Clause, regardless of any religious burden it may impose on the HosannaTabor Evangelical Lutheran Church and School-though it is not at all certain that compliance with the ADA burdens the school. In addition, to the extent that Perich's case raises Establishment Clause problems, it is the Court deciding whether she is a minister that raises such problems, not deciding whether the school retaliated against her.

Jones v. Wolf approves a better approach: Apply employment discrimination law to a religious employer in the same way it would be applied to a secular employer. If a theological or doctrinal question comes up, defer to the religious institution on that issue. Notably, accepting the employer's answer to a theological question does not guarantee that the religious employer will prevail. Even if it violates religious tenets to pay ministers the minimum wage, a religious school might still be required to obey the law. ${ }^{86}$ Likewise, it may violate religious tenets for ministers to assert their legal rights, but religious employers might not be able to fire someone for doing so. That is the holding of Employment Division $v$. Smith: Religion is no longer grounds for exemptions from neutral laws of general applicability. Only if compliance with anti-discrimination law

chaplain could not bring a Title VII sex discrimination claim).

81 See, e.g., Tomic v. Catholic Diocese of Peoria, 442 F.3d 1036, 1040-41 (7th Cir. 2006) (holding that a music director could not bring an ADEA claim).

82 Fassl v. Our Lady of Perpetual Help Roman Catholic Church, No. Civ.A. 05-CV-0404, 2005 WL 2455253 , at $* 2$ (E.D. Pa. Oct. 5, 2005) (holding that a director of music is precluded from bringing an FMLA suit).

83 See, e.g., Alcazar v. Corp. of the Catholic Archbishop of Seattle, 598 F.3d 668, 676-77 (9th Cir. 2010) (holding that a seminarian who performed maintenance work and assisted with mass could not bring a Washington Minimum Wage Act claim) (link); Schleicher v. Salvation Army, 518 F.3d 472, 477-78 (7th Cir. 2008) (holding that Salvation Army ministers who ran a rehabilitation center could not bring an FLSA claim for violating minimum wage and overtime requirements) (link); Shaliehsabou v. Hebrew Home of Greater Wash., 363 F.3d 299, 307 (4th Cir. 2004) (holding that a kosher supervisor of a Jewish nursing home was barred from bringing an FLSA claim) (link).

84 See, e.g., Skrzypczak v. Roman Catholic Diocese of Tulsa, 611 F.3d 1238, 1241 (10th Cir. 2010) (holding that the director of the Department of Religious Formation could not bring an Equal Pay Act claim) (link).

85 See, e.g., id. (holding that a director of the Department of Religious Formation could not bring a Title VII hostile work environment claim); Klouda v. Sw. Baptist Theological Seminary, 543 F. Supp. 2d 594, 612 (N.D. Tex. 2008) (holding that a professor was barred from bringing breach of contract, fraud, and promissory estoppel claims) (link).

86 Tony \& Susan Alamo Found. v. Sec'y of Labor, 471 U.S. 290, 303-06 (1985) (holding that the state could force a religious organization to violate its religious beliefs and pay the minimum wage, as required by the Fair Labor Standards Act). 
NORTHWESTERN UNIVERSITY LAW REVIEW COLLOQUY

undermines a religious message might one's right to freedom of association trump anti-discrimination law. 